Review Article

\title{
A Review of Intermediate Pyrolysis as a Technology of Biomass Conversion for Coproduction of Biooil and Adsorption Biochar
}

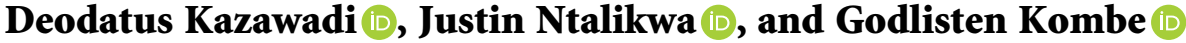 \\ Department of Petroleum and Energy Engineering, The University of Dodoma, P. O. Box 259, Dodoma, Tanzania \\ Correspondence should be addressed to Deodatus Kazawadi; dkazawadi@gmail.com
}

Received 22 February 2021; Revised 13 April 2021; Accepted 13 May 2021; Published 24 May 2021

Academic Editor: Abdurrahman Saydut

Copyright (c) 2021 Deodatus Kazawadi et al. This is an open access article distributed under the Creative Commons Attribution License, which permits unrestricted use, distribution, and reproduction in any medium, provided the original work is properly cited.

\begin{abstract}
The agenda to utilize and efficiently convert biomass has been raised to alleviate environmental problems and pressure on the reliance on fossil fuel. Intermediate pyrolysis has the ability to treat different biomasses and coproduction of biooil and adsorption biochar. This review article aims to evaluate the appropriateness of intermediate pyrolysis for the coproduction of biooil and adsorption biochar. It was observed that coproduced biooil is of high quality, stable, and miscible that can be used directly to existing engines or be easily blended. The biochar coproduced is good for adsorption but is not stable for microbial attack and hence unsuitable in soil treatment but for hydrometallurgy. Since the process is capable of treating waste biomass, it is an opportunity for further investigations in areas where wastes are plenty and less utilized. To increase the effectiveness of this technology for coproduction, optimizing parameters, design of efficient reactors, and use of catalyst must be worked upon.
\end{abstract}

\section{Introduction}

The ever increasing demand for energy and environmental protection concern has led to innovations on the appropriate conversion of nonrenewables and utilization of renewables $[1,2]$. Currently, much emphasis has been on renewable energies such as biomass. The utilization of both fresh and waste biomass is advantageous in terms of energy recovery and environmental protection [3,4]. The effective use of waste has been regarded as the backbone of the circular economy, effective energy conversion, and environmental protection [5]. In developing countries, organic biomass wastes have the potential to provide about $20-40 \%$ of the primary energy [6], and its effective conversion can bring sustainable energy and environment.

Different biomass conversion methods exist including direct combustion, biological, and thermochemical $[7,8]$, but thermochemical conversions have gained advantages over others $[9,10]$. They are effective, environmentally friendly, fast, of low maintenance and labor costs, selective in targeting specific product, and able to convert biomasses which do not compete with food such as biomass wastes [11].
Among the promising innovations, pyrolysis has been appreciated in converting biomass [11] into useful products, which are solid, liquid, and gas in an effective way. Pyrolysis is a thermochemical decomposition of organic material in the absence of oxygen [12]. The distribution and quality of the products depend on effective control of process parameters, the type of reactor, and feedstocks $[13,14]$. The products that have found great use that come from pyrolysis are biooil and biochar. Biochar derived from pyrolysis processes can be used as an adsorption agent and hence can reduce the use of fossil fuels in the production of the ever increasing demand for adsorbents [15]. Biooil produced from biomass pyrolysis can be used directly or with blending in engines and thus replace fossil oils.

Pyrolysis reaction may proceed as slow, intermediate, fast, or flash depending on the process operating parameters. Table 1 provides the range of operating parameters and product distribution of different categories of pyrolysis processes. It can be seen that slow and fast pyrolysis target biochar and biooil, respectively, while intermediate pyrolysis produces both simultaneously. Intermediate pyrolysis has been reported to be a type of pyrolysis that has a good 
TABle 1: Classification of pyrolysis processes [29-34].

\begin{tabular}{|c|c|c|c|c|}
\hline Property & Slow & Intermediate & Fast & Flash \\
\hline Heating rate $\left({ }^{\circ} \mathrm{C} / \mathrm{s}\right)$ & $1.1-1$ & $1-10$ & $10-200$ & $>1000$ \\
\hline Feed size $(\mathrm{mm})$ & $5-50$ & $1-5$ & $<1$ & $<0.5$ \\
\hline Reaction temperature $\left({ }^{\circ} \mathrm{C}\right)$ & $400-500$ & $400-650$ & $850-1250$ & $>1000$ \\
\hline Vapor residence time (s) & $300-550$ & $0.5-20$ & $0.5-10$ & $<1$ \\
\hline Feed water content $(\%)$ & Up to 40 & Up to 40 & $<<10$ & $<<10$ \\
\hline Biooil yield (\%) & $20-50$ & $35-50$ & $60-75$ & $60-75$ \\
\hline Biochar yield (\%) & $25-35$ & $25-40$ & $10-25$ & $10-25$ \\
\hline Gas yield (\%) & $20-50$ & $20-30$ & $10-30$ & $10-30$ \\
\hline
\end{tabular}

distribution and quality of the three products $[5,16-18]$ and hence the possibility of coproduction of biooil and adsorption biochar.

Due to the high demand for biooil and adsorption biochar, the need for utilization of wastes, need for extra upgrading treatment procedures of fast pyrolysis biooil, and low quality and quantity of biochar from fast pyrolysis, intermediate pyrolysis seems to be a way to go. This new technology is regarded as a promising technology especially in coproduction and utilization of different biomass. Several researchers have published on intermediate pyrolysis from various feedstocks and reactors, process conditions, and catalyst and have identified the benefits of the process. Unlike other pyrolysis reactions, intermediate has been reported to have advantages such as low operating temperature, ability to treat a range of feedstock, and production of high quality products [19-22]. Tinwala et al. [23] researched agroindustrial biomasses and wastes on a fixed bench-scale pyrolyzer, identified distribution of biooil of $20.5-47.5 \%$ and biochar of $27.5-40 \%$, and concluded that biooil can replace furnace oil. Mohammed et al. [24] studied the utilization of groundnuts shell in a vertically fixed bed reactor and found out that, among other things, the organic phase was of good quality and can be used as the precursor for chemicals. Other publications on intermediate pyrolysis have also reported its efficiency in treating wastes and producing quality biooil and biochar products [25-28].

The data that have been accessed shed light on the use of intermediate pyrolysis to generate usable biooil and biochar. Data on product characterization and quantity are available from a variety of feedstocks and reactors. Data on intermediate pyrolysis on some feedstocks and reactors show that coproducts are of high quality and can be used directly or with minimal processing as compared to other processes. Since this method is emerging and suitable for coproduction, data on product quality comparisons with other manufacturing processes should be available. Currently, such a comparison is not well documented. Thus, the comparison can give more emphasis on its utilization while enjoying the mentioned advantages above. Thus, this review article aimed at reviewing the possibilities of utilizing intermediate pyrolysis in the coproduction of biooil and adsorption biochar. These coproduced products should be of high quality, such that they can be used directly or with little upgrading. This was done by comparing the products from fast, slow, and intermediate pyrolysis, biodiesel, fossil diesel, and commercially activated carbon. The study also aimed at reviewing the possibilities of using intermediate pyrolysis in the utilization of the ever increasing and difficult wastes that are difficult to be handled by fast pyrolysis.

\section{Intermediate Pyrolysis}

Intermediate pyrolysis is the pyrolysis which is between fast pyrolysis and slow pyrolysis. From Table 1, intermediate pyrolysis has a good distribution of product and hence can be used in the coproduction of biochar, biooil, and gas [35]. Compared to other categories, intermediate pyrolysis has been reported to be flexible to various materials and has good product distribution, two phase's separable biooil, high quality, and dry biochar [5, 16-18, 31, 36-38]. Its ability to treat waste biomass gives it advantages to be used in developing countries where waste biomass such as municipal solid wastes currently is a problem [12, 37]. Researchers also have documented that it has easily separable liquid phases with the organic phase having properties similar to biodiesel [37, 39-43]. The organic phase can be blended to $50 \%$ with fossil liquid [37]. Its aqueous phase is also useful in the production of biogas and ethanol, since it contains $\mathrm{C}_{2}-\mathrm{C}_{6}$ sugars, hydroxyacids, oligomers, and water soluble phenols $[28,35]$. This gives advantages of not only little biooil upgrading compared to fast pyrolysis oil but also a total utilization of all products. Intermediate pyrolysis has the ability to treat high moisture content feedstock, and when this occurs, the biochar achieves the properties of activated carbon due to comprehensive interaction with steam [37].

The mentioned advantages above indicate that intermediate pyrolysis is suitable for the coproduction of biooil and adsorption biochar. The published data should be analyzed and concluded on whether it can replace other categories in biomass conversion, especially when coproduction is required. The following sections will evaluate the properties of these products and compare them with products from other categories and available commercial products, fossil diesel, biodiesel, and activated carbon.

2.1. Biochar. This is a solid carbon-rich product produced from pyrolysis with quality comparable to industrial coal, with a high amount of carbon and less amount of oxygen and hydrogen $[44,45]$. It has a microporous structure that is used in soil quality control and acts as activated carbon in the removal of metals such as chromium, cadmium, nickel, mercury, lead, gold, and silver from solution [46-50]. 
Intermediate biochar has properties suitable for energy and adsorption [20]. It is a dry, high energetic, brittle structure, and less dust and tar, and hence less toxic [51, 52]. It has a heating value similar to semibituminous coal [39]. It is also suitable as an adsorbent, and its quality increases as feed moisture content increases [37]. Since intermediate pyrolysis can process high moisture content feedstock, it can be expected to have high quality biochar since steam acts as activating agents.

Always, a good adsorbent should have the high adsorptive capacity, adsorption rate, mechanical strength, and wear resistance, reactivation characteristics, and good particle size distribution [53]. Biochar to be used as an adsorbent with high absorption power and affinity to metals are those with lower carbon, high nitrogen and oxygen, as well as lower $\mathrm{C} / \mathrm{N}$ and higher $\mathrm{O} / \mathrm{C}$ and $\mathrm{H} / \mathrm{C}$ ratios, higher pore volume, and higher $\mathrm{pH}$ [54]. It is always produced with low pyrolysis temperature at high pyrolysis time. Apart from slow pyrolysis, intermediate pyrolysis can be a good method of producing biochar with the ability to act as activated carbon.

Table 2 provides available published data on biochar from slow, intermediate, fast pyrolysis, and commercial activated carbon. The assessment on whether biochar from intermediate pyrolysis has a higher quality to be used as activated carbon is done by assessing the properties of different production techniques and commercially activated carbon. It can be seen that biochar from intermediate pyrolysis is drier $(0.7-4 \%)$ than fast (3-6\%) and slow $(2-42 \%)$ pyrolysis. High moisture content in commercial activated carbon is higher than those from intermediate due to water introduced during activation. Lower moisture content is advantageous in transport and storage. In terms of adsorption, the effect is not noticeable as moisture content does not affect adsorption capability [55].

While ash is not necessary, its composition is critical because the choice of metal to be adsorbed is influenced by the composition of ash, which can either impede or favor the process. There is not much of a difference in ash content between the items that are being compared. Adsorption is regulated by $\mathrm{pH}$ as well. In metal adsorption, an increase in $\mathrm{pH}$ simultaneously increases adsorption but is limited to a certain level [56]. From Table 2, it can be seen that biochar from intermediate pyrolysis has a $\mathrm{pH}$ range (8-9.6) close to activated carbon (5-8) and thus effective in metal adsorption compared to fast (7-11) and slow (6-12).

The rate of adsorption is controlled by high pores volume [53]. From published data, biochar from fast pyrolysis has a higher pore volume $\left(0.1-1 \mathrm{~cm}^{3} / \mathrm{g}\right)$ close to activated carbon $\left(0.05-1.5 \mathrm{~cm}^{3} / \mathrm{g}\right)$ compared to intermediate $\left(0.05-0.16 \mathrm{~cm}^{3} /\right.$ g) and slow of less than $0.14 \mathrm{~cm}^{3} / \mathrm{g}$ (Table 2). The higher value of pore volume of biochar from fast pyrolysis is favored by high operating temperatures $[93,94]$. This makes biochar from intermediate to be superior to those from slow pyrolysis. Furthermore, a good adsorbent should have high adsorption capacity which is determined by surface area. From published data in Table 2, biochar from intermediate pyrolysis has a high surface area $\left(100-250 \mathrm{~m}^{2} / \mathrm{g}\right)$ compared to fast $\left(15-110 \mathrm{~m}^{2} / \mathrm{g}\right)$, but less compared to activated carbon
(500-2058 $\left.\mathrm{m}^{2} / \mathrm{g}\right)$. The large surface area in slow and intermediate pyrolysis biochar is due to high residence time compared to fast pyrolysis [95, 96]. This allows utilizing biochar from intermediate pyrolysis for the activation process compared to fast pyrolysis biochar.

In terms of $\mathrm{H}: \mathrm{C}, \mathrm{C}: \mathrm{N}$, and $\mathrm{O}: \mathrm{C}$ ratios in which a good adsorbent should have lower $\mathrm{C} / \mathrm{N}$ and higher $\mathrm{O} / \mathrm{C}$ and $\mathrm{H} / \mathrm{C}$ ratios, biochar from intermediate pyrolysis is favored as adsorbent compared to those from slow and fast pyrolysis biochar. These ratios for intermediate pyrolysis biochar are much close to those of activated carbon. An important note is biochar from intermediate pyrolysis is more of adsorption rather than stability due to high ratios of $\mathrm{H}: \mathrm{C}$ and $\mathrm{O}: \mathrm{C}$. High $\mathrm{H}$ : C (low aromaticity) and high aliphatic content allow easy microbial attack [97]. Always, resistance to microbial reaction is achieved when the ratio of oxygen to carbon is less than 0.2 [98]. Thus, intermediate pyrolysis biochar is more of adsorption than stability and hence difficult to be used in soil adsorption. It is thus suitable in hydrometallurgical adsorption.

2.2. Biooil. Biooil can be defined as a condensate product of pyrolysis which is dark brown, viscous organic liquid comprised of several complex oxygenated compounds [99]. It has viscous water-insoluble tar, mainly the oligomeric lignin-containing fraction, which tends to spontaneously precipitate in the presence of a large amount of water [100]. It is thermally unstable due to the large amount of oxygen. For example, if stored for longer than two months, it becomes difficult to ignite and burn than fresh biooil [100]. The composition of biooil is dominated by the phenolic group (about 31\%), carbonyl group, followed by the carboxyl group $[27,101]$.

Biooil which is mostly produced from fast pyrolysis is reported to have poor combustibility and less miscibility and hence difficult to be used directly in normal engines [39]. This is due to high viscosity, oxygen, and water contents. It also has low thermal stability and high corrosiveness. This is because fast pyrolysis simply liquefies a part of feedstock and does not upgrade the molecule structure significantly, and hence, reactive chemical compounds are still in the oil [102]. Thus, biooil from fast pyrolysis cannot be utilized without prior upgrading. This adds extra cost in terms of the extra process and catalysts used. Biooil is the one with good properties compared to biodiesel and fossil diesel and thus can be used directly or with little upgrading.

When compared to biooil from fast pyrolysis, biooil from intermediate pyrolysis has improved physical and chemical properties, such as low oxygen content in biooil, better oil miscibility with fossil fuels, and high calorific value [27]. It is reported to have a low amount of tar and less reactive tar [103, 104]. These improvements in properties make biooil easy to use in existing engines. Table 3 summarizes the properties of biooil from intermediate and fast pyrolysis and compares it with diesel and biodiesel. Always, a good fuel should have low moisture, ash, sulphur, oxygen, and nitrogen contents and high amounts of carbon, hydrogen, and high heating value. 
TABLE 2: Comparison of biochar properties at different pyrolysis categories and activated carbon.

\begin{tabular}{|c|c|c|c|c|}
\hline \multirow{2}{*}{ Property } & \multicolumn{3}{|c|}{ Pyrolysis category } & \multirow{2}{*}{$\begin{array}{c}\text { Commercially } \\
\text { activated carbon }\end{array}$} \\
\hline & Slow & Fast & Intermediate & \\
\hline Water content (\%), wet basis & $2-42[57,58]$ & $3-6[59,60]$ & $0.7-4[21,61]$ & $1-12[62-67]$ \\
\hline Volatile matter (\%), dry basis & $7-41[57,58,68-70]$ & $11-27[59,60]$ & $15-29[21,25]$ & $7-21[64-66]$ \\
\hline Ash content (\%), dry basis & $1.4-9[58,68,70]$ & $8-12[59,60]$ & $3-14[19,21,25,39]$ & $2-13[62,64,71]$ \\
\hline Fixed carbon, dry basis & $26-91[57,68-70,72]$ & $58-75[59,60]$ & $55-65[21,25]$ & $76-89[64,66]$ \\
\hline $\mathrm{pH}$ & $6-12[58,69,70,73]$ & $7-11[59,73]$ & $8-9.6[19,20]$ & $5-8[62,64,74]$ \\
\hline Carbon (\%), dry ash free & $45-85[57,68,70,72]$ & $63-89[59,75]$ & $65-85[19-21,39,61]$ & $49-64[66,71]$ \\
\hline Hydrogen (\%), dry ash free & $0.3-7[57,68,70,73]$ & $0.3-4[59,73,75]$ & $0.5-4[19,20,39,61]$ & $0.5-4.52[66,67]$ \\
\hline Nitrogen (\%), dry ash free & $0.2-3[57,68,73]$ & $0.5-5[59,73,75]$ & $0.1-3[19,25,39,61]$ & $0.1-2[66,67]$ \\
\hline Oxygen (\%), dry ash free & $0.2-19[57,68,73]$ & $2-24[59,73,75,76]$ & $2.2-23[19,20,39,61]$ & $31-34[66,67,71]$ \\
\hline Average specific area $\left(\mathrm{m}^{2} / \mathrm{g}\right)$ & $0.4-370[58,70,72]$ & $15-110[60,77]$ & $100-250[19]$ & $500-2058[67,74,78-81]$ \\
\hline Total pore volume $\left(\mathrm{cm}^{3} / \mathrm{g}\right)$ & $0.0013-0.14[72,82]$ & $0.1-1[60,75]$ & $0.05-0.16[19,25]$ & $0.05-1.5[64,74,78,81]$ \\
\hline $\mathrm{H}: \mathrm{C}$ ratio (molar ratio) & $0.02-0.61[70,73,83,84]$ & $0.05-0.59[85-87]$ & $0.06-0.86[23,24,88]$ & $0.24-1.1[89-91]$ \\
\hline $\mathrm{C}: \mathrm{N}$ ratio (molar ratio) & $80-177[73,92]$ & $117-180[85-87]$ & $73-155[21,23]$ & $104-135[67,89]$ \\
\hline $\mathrm{O}: \mathrm{C}$ ratio (molar ratio) & $0.08-0.4[73,84,92]$ & $0.05-0.18[85-87]$ & $0.1-0.23[17,23,24,88]$ & $0.18-0.52[67,90]$ \\
\hline
\end{tabular}

TABLe 3: Comparison of fast and intermediate biooil, fossil diesel, and biodiesel fuels.

\begin{tabular}{|c|c|c|c|c|}
\hline Property & Intermediate & Fast & Diesel & Biodiesel \\
\hline Water (\%) & $1.7-15.3[20,39,61,104,108,109]$ & $15-30[107,110-112]$ & $0.05[108,113]$ & $0.05[108,114-116]$ \\
\hline dry basis & $0.16-0.23[20,39,108]$ & $0.01-1.5$ & $<0.1[108$ & $<0.2[1$ \\
\hline $\mathrm{C}(\%)$, dry ash free & $49-74[18,20,27,39,104,108,109]$ & $54-61[98,107,110,111]$ & $85.6[108,110,117]$ & $78.86[108,115,116]$ \\
\hline S (\%), dry ash free & $0.1-3.3[18,27,104,108,109]$ & $0.03-0.3[112,118]$ & $<0.8[108,110]$ & $\begin{array}{c}<0.74 \\
{[108,114-116]}\end{array}$ \\
\hline $\mathrm{O}(\%)$, dry ash free & $8.72-33[18,20,39,104,108,109]$ & $35-40[107,110,111]$ & $1.01[108,117]$ & $\begin{array}{c}8.36-11 \\
{[115,116,119]}\end{array}$ \\
\hline $\mathrm{H}(\%)$, dry ash free & $6.79-10.6[18,20,27,39,61,104,108,109]$ & $5.5-7[107,110]$ & $13.37[108,117]$ & $\begin{array}{c}11-13 \\
{[108,115,116]}\end{array}$ \\
\hline $\mathrm{N}(\%)$, dry ash free & $0.1-5.8[18,20,27,39,104,108,109]$ & $0.4-2[99,112]$ & $<0.1[108,117]$ & $0.1[108,115,116]$ \\
\hline $\begin{array}{l}\text { Density }(\mathrm{g} / \mathrm{cc}) \text {, at } \\
25^{\circ} \mathrm{C}\end{array}$ & $0.95-1.082[39,104,108]$ & $\begin{array}{c}1.14-1.2 \\
{[107,110,111,120]}\end{array}$ & $0.82[108,110]$ & $0.88[108,115,116]$ \\
\hline $\begin{array}{l}\text { Viscosity (cp), at } \\
40^{\circ} \mathrm{C}\end{array}$ & $2.82-98[39,104,109]$ & $15-100[111,112]$ & $\begin{array}{c}1.9-4.1 \\
{[108,110,113]}\end{array}$ & $1.9-6[108,114-116]$ \\
\hline $\mathrm{HHV}(\mathrm{MJ} / \mathrm{kg})$ & $22-40[18,20,26,27,38,39,61,104,108,109]$ & $16-19[98,107,110,111]$ & $\begin{array}{c}45-47 \\
{[108,110,113]}\end{array}$ & $\begin{array}{c}35-40 \\
{[115,116,121]}\end{array}$ \\
\hline
\end{tabular}

From published data (Table 3), intermediate biooil has low ash content $(<0.23)$ that is comparable to biodiesel $(<0.2$ $\%)$ and fossil diesel $(<0.1 \%)$ which is of high quality when compared to fast pyrolysis biooil that can reach $0.15 \%$. This leads to improved quality compared to fast pyrolysis biooil (up to $1.5 \%$ ). Water content in fuel is not required since it reduces heating value, causes corrosion, and increases viscosity [105]. High water content also causes phase separation, thus causing corrosion, troubles in the burner, and emulsion formation [106]. Furthermore, high content reduces heating value, stability, density, and raises $\mathrm{pH}$ $[105,107]$. Compared to fast pyrolysis biooil, intermediate pyrolysis biooil has less amount of water (2-15\%) compared to fast pyrolysis oil (15-30\%) (Table 3). When compared to fossil fuel and biodiesel, it can be seen that it can be a good candidate when blending with fossil fuel to produce low water content blend.

The high amount of hydrogen and carbon increases the quality of oil, and a low amount of oxygen, sulphur, and nitrogen reduces pollution. From Table 3, intermediate pyrolysis biooil has a high amount of carbon (49-74\%) and hydrogen (6-11\%) compared to fast pyrolysis biooil (hydrogen $4-7 \%$ and carbon $54-61 \%$ ) and is approaching biodiesel and fossil fuel. Intermediate pyrolysis biooil has less amount of oxygen (8-33\%) compared to fast pyrolysis oil (35-40\%) and approaching biodiesel (8\%). A high amount of oxygen in oil causes oil instability, low energy content, low miscibility, and increases $\mathrm{pH}$ [105]. This gives intermediate pyrolysis oil to be superior to fast pyrolysis oil and hence a candidate for blending with fossil fuel.

High viscosity causes difficulty inflow and hence problems in combustion. Intermediate pyrolysis has low viscosity (2-98 cp) compared to fast pyrolysis oil $(15-100 \mathrm{cp})$ and close to biodiesel and fossil diesel (Table 3 ). This makes it easy for combustion and transportation. Low viscosity and miscibility due to the low oxygen content in intermediate pyrolysis oil makes it easy to be blended with biodiesel or fossil diesel and hence easy utilization in normal engine compared to fast pyrolysis oil. Easy blending is also associated with the presence of about $12 \%$ fatty acid methyl esters in intermediate pyrolysis biooil [42]. Above all, intermediate pyrolysis oil has a 
higher heating value $(24-40 \mathrm{MJ} / \mathrm{kg})$ that is close to biodiesel (35-40 MJ/kg) and fossil diesel (45 MJ/kg) (Table 3). This makes it fit to be used as fuel, and with addition to above added advantages, it becomes superior to fast pyrolysis biooil.

\section{Intermediate Pyrolysis as the Appropriate Process for Waste Utilization}

The high demand for food and forest products for the ever increasing population has led to increased production of wastes. This increase in population and wastes put pressure on nonrenewable energy resources and the environment [122]. Poor treatment of wastes that lead to pollution and loss of energy is common in developing countries. If these wastes are well treated can generate $20-40 \%$ of primary energy in developing countries [123] and if well converted can help to reduce the pressure of feedstocks for biooil and adsorption biochar production.

An important challenge is to effectively treat these wastes at both environmental and economic effectiveness. The wastes contain a wide range of components that needs careful treatment before utilization. They may contain a high amount of water that may be difficult in direct combustion and fast and flash pyrolysis. They may also contain lignocellulosic materials that the biochemical process becomes difficult. Due to difficulties in collection and transportation, building large plants may not be economical. All the above challenges put the challenge on effective utilization of wastes at current common conversion methods. Therefore, a method that can take into account these challenges is required.

Intermediate pyrolysis is believed to be effective and environmental friendly in treating wastes. It has the ability to treat difficult low-value, high-ash wastes such as sewage wastes and deinking sludge that cannot be treated by fast pyrolysis [37]. It can handle different types of feedstock, large sizes, high moistures, and operates economically at any plant size and thus be able to treat wastes [12]. The process is more reliable and robust and hence appropriate to small and medium scale [31]. The use of large size and production of directly usable biooil makes it reduce costs in small and medium plants. Therefore, intermediate pyrolysis is a good candidate in the processing waste with little or no pretreatment procedure while producing good quality of products. Since intermediate pyrolysis is a candidate for coproduction of adsorption biochar and biooil, the conversion of wastes can be a resource and environment serving technology.

Intermediate pyrolysis study on the production biooil from Eucalyptus sp. and Picea abies wood wastes found out that there was little or no need of upgrading biooil when compared to fast pyrolysis of such wastes [31]. The study of organic part of municipal solid wastes has revealed the production of biooil which is stable and non-Newtonian [5]. The study by Del Pozo et al. [124] on coffee silver skin resulted to increased energy biochar and biooil with 200-500 tons of gallic acid equivalents per year. The 2021 study of grape waste (grape pomace) done by Del Pozo et al. [125] has indicated intermediate pyrolysis is effective than torrefaction in processing this waste and production of antioxidants. The study also indicated the production of both good biochar and biooil with two separable parts. The study by Yang et al. [126] has suggested the use of intermediate pyrolysis of wastes in China can be profitable without subsidiaries. The intermediate pyrolysis of sewage sludge and deinking sludge found out that the biooil had high carbon and hydrogen content and thus high heating value that is comparable to biodiesel, with easy storage and transportation at the economic level [26]. It has also been proved that intermediate pyrolysis of rice straw wastes proved to offset carbon dioxide than the rest of types [32]. Other intermediate pyrolysis studies on wastes such as organic fraction of municipal solid wastes [12], sugarcane bagasse [127], sugarcane bagasse and oat hulls [128], chicken manure for fertilizer and heat production [5], wheat husk [27], waste tires [129], and Bambara groundnut shells [24] have appreciated the advantages of intermediate pyrolysis. These good results indicate the effectiveness of intermediate pyrolysis on the conversion of wastes when compared to current common technologies. Due to its ability to coproduce biooil and adsorption biochar, wastes are thus good candidate feedstock for the coproduction.

\section{Opportunities and Challenges of Intermediate Pyrolysis}

Intermediate pyrolysis is a relatively new technology but has shown more advantages such as ability to handle difficult feedstock [130]. It produces three products that have quality to be used directly or with little upgrade $[52,131]$. It has a big chance of becoming a viable technology especially in treating wastes that currently are accumulating worldwide and hence reduce the cost of feedstock treatment and products upgrading. It also has a big opportunity of operating at small and medium plants, since it is still economically beneficial at a small scale. It also has a big opportunity in the coproduction of biooil and adsorption biochar that needs little or no upgrading. Such prospective opportunities have been raised in the economic benefit of treating coconut shell to produce high quality biooil [132], the combined heat and power production of intermediate pyrolysis related to economy and environment [37]. In other studies, such as noted in Section 4 in the utilization of wastes, intermediate pyrolysis gives the opportunity to recover energy and protect the environment from biomass waste materials.

The challenges that face this novel technology include the utilization of an aqueous phase which contains a certain amount of energy. A study done by Torri and Fabbri [28] showed that its utilization in biogas production required prior treatment or use of catalysts. Also, good distribution and quality depend on parameter control [132] and the use of appropriate reactors. Some promising reactors have been designed and others are in progress [130]. It is now an appropriate time to increase the research on optimization of parameters for coproduction of adsorption biochar and biooil. Also, more studies should be done to include the use of catalyst to increase the quality of products. 


\section{Conclusion}

This review article has analyzed the possibility of utilizing intermediate pyrolysis as an emerging technology in the coproduction of biooil and adsorption biochar. The observed advantages of good product distribution and simultaneous production of biooil and biochar make it a candidate in the coproduction of biooil and adsorption biochar. The analysis has shown that the organic biooil has high quality that is comparable to biodiesel and fossil oil. It has a high heating value, low viscosity, high stability, and miscibility making it superior to biooil from fast pyrolysis. Also, the comparison has shown that biochar from intermediate pyrolysis is more suitable for hydrometallurgical adsorption and is thus used as activated carbon. It was also realized that it can effectively treat wastes that have varying composition, high moisture content, and large size and thus become a candidate for coproduction of biooil and activated carbon for the ever increasing wastes.

\section{Conflicts of Interest}

The authors declare that they have no conflicts of interest.

\section{Acknowledgments}

The authors would like to appreciate the contribution made by the University of Dodoma in assisting with financial assistance for this review article.

\section{References}

[1] Z. A. Elum and A. S. Momodu, "Climate change mitigation and renewable energy for sustainable development in Nigeria: a discourse approach," Renewable and Sustainable Energy Reviews, vol. 76, pp. 72-80, 2017.

[2] A. S. Oyewo, A. Aghahosseini, D. Bogdanov, and C. Breyer, "Pathways to a fully sustainable electricity supply for Nigeria in the mid-term future," Energy Conversion and Management, vol. 178, pp. 44-64, 2018.

[3] H. A. Alhashimi and C. B. Aktas, "Life cycle environmental and economic performance of biochar compared with activated carbon: a meta-analysis," Resources, Conservation and Recycling, vol. 118, pp. 13-26, 2017.

[4] M. H. Kim, I. T. Jeong, S. B. Park, and J. W. Kim, "In analysis of environmental impact of activated carbon production from wood waste," Environmental Engineering Research, vol. 24, no. 1, pp. 117-126, 2018.

[5] M. T. Morgano, B. Bergfeldt, H. Leibold, F. Richter, and D. Stapf, "Intermediate pyrolysis of agricultural waste: a decentral approach towards circular economy," Chemical Engineering Transactions, vol. 65, pp. 649-654, 2018.

[6] A. Kumar, S. R. Samadder, and S. R. Samadder, "A review on technological options of waste to energy for effective management of municipal solid waste," Waste Management, vol. 69, pp. 407-422, 2017.

[7] S. Yilmaz and H. Selim, "A review on the methods for biomass to energy conversion systems design," Renewable and Sustainable Energy Reviews, vol. 25, pp. 420-430, 2013.

[8] M. Pande and A. N. Bhaskarwar, "Biomass conversion to energy," in Biomass Conversion, pp. 1-90, Springer, Berlin, Germany, 2012.
[9] X.-G. Zhao, G.-W. Jiang, A. Li, and L. Wang, "Economic analysis of waste-to-energy industry in China," Waste Management, vol. 48, pp. 604-618, 2016.

[10] S. T. Tan, W. S. Ho, H. Hashim et al., "Energy, economic and environmental (3E) analysis of waste-to-energy (WTE) strategies for municipal solid waste (MSW) management in Malaysia," Energy Conversion and Management, vol. 102, pp. 111-120, 2015.

[11] V. Dhyani and T. Bhaskar, "A comprehensive review on the pyrolysis of lignocellulosic biomass," Renewable Energy, vol. 129, pp. 695-716, 2018.

[12] Y. Yang, Y. Zhang, E. Omairey, J. Cai, F. Gu, and A. V. Bridgwater, "Intermediate pyrolysis of organic fraction of municipal solid waste and rheological study of the pyrolysis oil for potential use as bio-bitumen," Journal of Cleaner Production, vol. 187, pp. 390-399, 2018.

[13] T. Kan, V. Strezov, and T. J. Evans, "Lignocellulosic biomass pyrolysis: a review of product properties and effects of pyrolysis parameters," Renewable and Sustainable Energy Reviews, vol. 57, pp. 1126-1140, 2016.

[14] R. E. Guedes, A. S. Luna, and A. R. Torres, "Operating parameters for bio-oil production in biomass pyrolysis: a review," Journal of Analytical and Applied Pyrolysis, vol. 129, pp. 134-149, 2018.

[15] J. Lamb, "Activated carbon market size, share, report, analysis, trends \& forecast to 2026,” 2018, https://www.reuters.com/ brandfeatures/venture-capital/article?id=47577.

[16] A. Hornung, "Intermediate pyrolysis of biomass," in Biomass Combustion Science, Technology and Engineering, L. Rosendahl, Ed., Woodhead Publishing: Aston, Birmingham, UK, pp. 172-186, 2013.

[17] A. Hornung and E. Schröder, "Production of biochar and activated carbon via intermediate pyrolysis-recent studies for non-woody biomass," Transformation of Biomass, JohnWiley \& Sons Ltd., pp. 321-338, New Delhi, India, 2014.

[18] C. Boscagli, M. Tomasi Morgano, K. Raffelt, H. Leibold, and J.-D. Grunwaldt, "Influence of feedstock, catalyst, pyrolysis and hydrotreatment temperature on the composition of upgraded oils from intermediate pyrolysis," Biomass and Bioenergy, vol. 116, pp. 236-248, 2018.

[19] S.-H. Jung and J.-S. Kim, "Production of biochars by intermediate pyrolysis and activated carbons from oak by three activation methods using $\mathrm{CO}_{2}$," Journal of Analytical and Applied Pyrolysis, vol. 107, pp. 116-122, 2014.

[20] A. Ahmed, M. S. Abu Bakar, A. K. Azad, R. S. Sukri, and N. Phusunti, "Intermediate pyrolysis of Acacia cincinnata and Acacia holosericea species for bio-oil and biochar production," Energy Conversion and Management, vol. 176, pp. 393-408, 2018.

[21] M. Buffi, A. M. Rizzo, L. Pari, and D. Chiaramonti, "Intermediate pyrolysis campaign to assess products yield and quality varying biomass particles size, temperatures and composition," International Journal of Oil, Gas and Coal Technology, vol. 17, no. 3, pp. 355-373, 2018.

[22] G.-G. Choi, S.-J. Oh, and J.-S. Kim, "Intermediate pyrolysis of scrap tires in a fixed bed reactor and activation of the pyrolysis char using $\mathrm{CO}_{2}$ : characteristics of pyrolysis products and activated char," in Proceedings of the 7th International Symposium on Feedstock Recycling of Polymeric Materials, New Delhi, India, October 2013.

[23] F. Tinwala, P. Mohanty, S. Parmar, A. Patel, and K. K. Pant, "Intermediate pyrolysis of agro-industrial biomasses in bench-scale pyrolyser: product yields and its characterization," Bioresource Technology, vol. 188, pp. 258-264, 2015. 
[24] I. Y. Mohammed, Y. A. Abakr, M. Musa, S. Yusup, A. Singh, and F. K. Kazi, "Valorization of Bambara groundnut shell via intermediate pyrolysis: products distribution and characterization," Journal of Cleaner Production, vol. 139, pp. 717-728, 2016.

[25] I. Y. Mohammed, Y. A. Abakr, S. Yusup, and F. K. Kazi, "Valorization of Napier grass via intermediate pyrolysis: optimization using response surface methodology and pyrolysis products characterization," Journal of Cleaner Production, vol. 142, pp. 1848-1866, 2017.

[26] M. Ouadi, J. G. Brammer, Y. Yang, A. Hornung, and M. Kay, "The intermediate pyrolysis of de-inking sludge to produce a sustainable liquid fuel," Journal of Analytical and Applied Pyrolysis, vol. 102, pp. 24-32, 2013.

[27] J. Santos, M. Ouadi, H. Jahangiri, and A. Hornung, "Integrated intermediate catalytic pyrolysis of wheat husk," Food and Bioproducts Processing, vol. 114, pp. 23-30, 2019.

[28] C. Torri and D. Fabbri, "Biochar enables anaerobic digestion of aqueous phase from intermediate pyrolysis of biomass," Bioresource Technology, vol. 172, pp. 335-341, 2014.

[29] H. Jouhara, D. Ahmad, I. Van Den Boogaert, E. Katsou, S. Simons, and N. Spencer, "Pyrolysis of domestic based feedstock at temperatures up to $300^{\circ} \mathrm{C}$," Thermal Science and Engineering Progress, vol. 5, pp. 117-143, 2018.

[30] M. Tripathi, J. N. Sahu, J. N. Sahu, and P. Ganesan, "Effect of process parameters on production of biochar from biomass waste through pyrolysis: a review," Renewable and Sustainable Energy Reviews, vol. 55, pp. 467-481, 2016.

[31] I. D. V. Torri, V. Paasikallio, C. S. Faccini et al., "Bio-oil production of softwood and hardwood forest industry residues through fast and intermediate pyrolysis and its chromatographic characterization," Bioresource Technology, vol. 200, pp. 680-690, 2016.

[32] X. Gong, C.-C. Kung, and L. Zhang, "An economic evaluation on welfare distribution and carbon sequestration under competitive pyrolysis technologies," Energy Exploration \& Exploitation, vol. 39, no. 2, pp. 553-570, 2021.

[33] X. J. Lee, H. C. Ong, Y. Y. Gan, W.-H. Chen, and T. M. I. Mahlia, "State of art review on conventional and advanced pyrolysis of macroalgae and microalgae for biochar, bio-oil and bio-syngas production," Energy Conversion and Management, vol. 210, Article ID 112707, 2020.

[34] S. Nanda and B. Franco, "Thermochemical conversion of plastic waste to fuels: a review," Environmental Chemistry Letters, vol. 19, no. 1, pp. 123-148, 2020.

[35] I. N. Zaini, N. Sophonrat, K. Sjöblom, and W. Yang, "Creating values from biomass pyrolysis in Sweden: Coproduction of $\mathrm{H}_{2}$, biocarbon and bio-oil," Processes, vol. 9, no. 3, p. 415, 2021.

[36] T. Bridgwater, "Challenges and opportunities in fast pyrolysis of biomass: part II," Johnson Matthey Technology Review, vol. 62, no. 2, pp. 150-160, 2018.

[37] Y. Yang, J. G. Brammer, D. G. Wright, J. A. Scott, C. Serrano, and A. V. Bridgwater, "Combined heat and power from the intermediate pyrolysis of biomass materials: performance, economics and environmental impact," Applied Energy, vol. 191, pp. 639-652, 2017.

[38] M. Elmously, N. Jäger, J. Neidel, A. Apfelbacher, R. Daschner, and A. Hornung, "Upscaling of thermo-catalytic reforming process from lab to pilot scale," Industrial \& Engineering Chemistry Research, vol. 58, no. 35, pp. 1585315862, 2019.

[39] Y. Yang, J. G. Brammer, A. S. N. Mahmood, and A. Hornung, "Intermediate pyrolysis of biomass energy pellets for producing sustainable liquid, gaseous and solid fuels," Bioresource Technology, vol. 169, pp. 794-799, 2014.

[40] G. Yildiz, F. Ronsse, R. Venderbosch, R. V. Duren, S. R. A. Kersten, and W. Prins, "Effect of biomass ash in catalytic fast pyrolysis of pine wood," Applied Catalysis B: Environmental, vol. 168-169, pp. 203-211, 2015.

[41] Y. Yang, J. G. Brammer, J. Samanya, A. K. Hossain, and A. Hornung, "Investigation into the performance and emissions of a stationary diesel engine fuelled by sewage sludge intermediate pyrolysis oil and biodiesel blends," Energy, vol. 62, pp. 269-276, 2013.

[42] A. K. Hossain, M. Ouadi, S. U. Siddiqui et al., "Experimental investigation of performance, emission and combustion characteristics of an indirect injection multi-cylinder CI engine fuelled by blends of de-inking sludge pyrolysis oil with biodiesel," Fuel, vol. 105, pp. 135-142, 2013.

[43] A. M. Warhurst, G. L. Mcconnachie, and S. J. T. Pollard, "Characterisation and applications of activated carbon produced from Moringa oleifera seed husks by single-step steam pyrolysis," Water Research, vol. 31, no. 4, pp. 759-766, 1997.

[44] P. Fu, S. Hu, J. Xiang, L. Sun, S. Su, and J. Wang, "Evaluation of the porous structure development of chars from pyrolysis of rice straw: effects of pyrolysis temperature and heating rate," Journal of Analytical and Applied Pyrolysis, vol. 98, pp. 177-183, 2012.

[45] P. Mohanty, K. K. Pant, S. N. Naik, J. Parikh, A. Hornung, and J. N. Sahu, "Synthesis of green fuels from biogenic waste through thermochemical route-the role of heterogeneous catalyst: a review," Renewable and Sustainable Energy Reviews, vol. 38, pp. 131-153, 2014.

[46] M. Balat, "An overview of the properties and applications of biomass pyrolysis oils," Energy Sources, Part A: Recovery, Utilization, and Environmental Effects, vol. 33, no. 7, pp. 674-689, 2011.

[47] S. Malghani, G. Gleixner, and S. E. Trumbore, "Chars produced by slow pyrolysis and hydrothermal carbonization vary in carbon sequestration potential and greenhouse gases emissions," Soil Biology and Biochemistry, vol. 62, pp. 137146, 2013.

[48] M. P. Mchenry, "Agricultural bio-char production, renewable energy generation and farm carbon sequestration in Western Australia: certainty, uncertainty and risk," Agriculture, Ecosystems \& Environment, vol. 129, no. 1-3, pp. 1-7, 2009.

[49] D. Mohan, S. Rajput, V. K. Singh, P. H. Steele, and C. U. Pittman Jr., "Modeling and evaluation of chromium remediation from water using low cost bio-char, a green adsorbent," Journal of Hazardous Materials, vol. 188, no. 1-3, pp. 319-333, 2011.

[50] D. Mohan, A. Sarswat, Y. S. Ok, and C. U. Pittman Jr., "Organic and inorganic contaminants removal from water with biochar, a renewable, low cost and sustainable adsorbent-a critical review," Bioresource Technology, vol. 160, pp. 191-202, 2014.

[51] K. Kebelmann, A. Hornung, U. Karsten, and G. Griffiths, "Intermediate pyrolysis and product identification by TGA and Py-GC/MS of green microalgae and their extracted protein and lipid components," Biomass and Bioenergy, vol. 49 , pp. 38-48, 2013

[52] A. Hornung, A. Apfelbacher, and S. Sagi, "Intermediate pyrolysis: a sustainable biomass-to-energy concept-Biothermal valorisation of biomass (BtVB) process," Journal of 
Scientific and Industrial Research, vol. 70, no. 8, pp. 664-667, 2011.

[53] J. Marsden and I. House, The Chemistry of Gold Extraction, SME, Englewood, CO, USA, 2006.

[54] E. Thomas, N. Borchard, C. Sarmiento, R. Atkinson, and B. Ladd, "Key factors determining biochar sorption capacity for metal contaminants: a literature synthesis," Biochar, vol. 2, pp. 151-163, 2020.

[55] S. Madhavakrishnan, K. Manickavasagam, K. Rasappan, P. S. S. Shabudeen, R. Venkatesh, and S. Pattabhi, "Ricinus CommunisPericarp activated carbon used as an adsorbent for the removal of $\mathrm{Ni}$ (II) from aqueous solution," E-journal of Chemistry, vol. 5, no. 4, pp. 761-769, 2008.

[56] E. A. Deliyanni, G. Z. Kyzas, K. S. Triantafyllidis, and K. A. Matis, "Activated carbons for the removal of heavy metal ions: a systematic review of recent literature focused on lead and arsenic ions," Open Chemistry, vol. 13, no. 1, 2015.

[57] N. Gómez, J. G. Rosas, J. Cara et al., "Slow pyrolysis of relevant biomasses in the Mediterranean basin. Part 1. Effect of temperature on process performance on a pilot scale," Journal of Cleaner Production, vol. 120, pp. 181-190, 2016.

[58] J. A. Alburquerque, M. E. Sánchez, M. Mora, and V. Barrón, "Slow pyrolysis of relevant biomasses in the Mediterranean basin. Part 2. Char characterisation for carbon sequestration and agricultural uses," Journal of Cleaner Production, vol. 120, pp. 191-197, 2016.

[59] R. S. Chutia, R. Kataki, and T. Bhaskar, "Characterization of liquid and solid product from pyrolysis of Pongamia glabra deoiled cake," Bioresource Technology, vol. 165, pp. 336-342, 2014.

[60] X. Li, X. Guo, S. Wang, K. Wang, Z. Luo, and Qi Wang, "Characterization and analysis of char produced by biomass fast pyrolysis," in Proceedings of the 2010 Asia-Pacific Power and Energy Engineering Conference, IEEE, Chengdu, China, March 2010.

[61] J. Neumann, S. Binder, A. Apfelbacher, J. R. Gasson, P. Ramírez García, and A. Hornung, "Production and characterization of a new quality pyrolysis oil, char and syngas from digestate - introducing the thermo-catalytic reforming process," Journal of Analytical and Applied Pyrolysis, vol. 113, pp. 137-142, 2015.

[62] S. Hemsas, H. Lounici, Z. Belkebi, and K. Benrachedi, "Removal of dispersed dyes from aqueous solution using activated carbon prepared from olive stones," Journal of Agricultural Science and Technology: A, vol. 4, no. 5A, 2014.

[63] Z. Al-Qodah and R. Shawabkah, "Production and characterization of granular activated carbon from activated sludge," Brazilian Journal of Chemical Engineering, vol. 26, no. 1, pp. 127-136, 2009.

[64] S. Das, S. Mishra, "Characterization of activated carbon of coconut shell, rice husk and Karanja oil cake," 2014.

[65] V. Viena and M. Nizar, "Characterization of activated carbon prepared from banana peels: effect of chemical activators on the adsorption of gas emissions," in Journal of Physics: Conference SeriesIOP Publishing, Bristol, UK, 2019.

[66] A. Kumar and H. M. Jena, "Preparation and characterization of high surface area activated carbon from Fox nut (Euryale ferox) shell by chemical activation with $\mathrm{H}_{3} \mathrm{PO}_{4}$, " Results in Physics, vol. 6, pp. 651-658, 2016.

[67] A. Colomba, "Production of activated carbons from pyrolytic char for environmental applications," in Chemical and Biochemical EngineeringUniversity of Western Ontario, Ontario, Canada, 2015.
[68] K. Chaiwong, T. Kiatsiriroat, N. Vorayos, and C. Thararax, "Biochar production from freshwater algae by slow pyrolysis," Maejo International Journal of Science and Technology, vol. 6, no. 2, p. 186, 2012.

[69] S. Yu, J. Park, M. Kim, C. Ryu, and J. Park, "Characterization of biochar and byproducts from slow pyrolysis of hinoki cypress," Bioresource Technology Reports, vol. 6, pp. 217-222, 2019.

[70] F. Ronsse, S. Van Hecke, D. Dickinson, and W. Prins, "Production and characterization of slow pyrolysis biochar: influence of feedstock type and pyrolysis conditions," GCB Bioenergy, vol. 5, no. 2, pp. 104-115, 2013.

[71] M. Ossman, M. Abdel Fatah, and N. A. Taha, "Fe (III) removal by activated carbon produced from Egyptian rice straw by chemical activation," Desalination and Water Treatment, vol. 52, no. 16-18, pp. 3159-3168, 2014.

[72] Y. Lee, P.-R.-B. Eum, C. Ryu, Y.-K. Park, J.-H. Jung, and S. Hyun, "Characteristics of biochar produced from slow pyrolysis of Geodae-Uksae 1," Bioresource Technology, vol. 130 , pp. $345-350,2013$

[73] E. W. Bruun, P. Ambus, H. Egsgaard, and H. HauggaardNielsen, "Effects of slow and fast pyrolysis biochar on soil C and N turnover dynamics," Soil Biology and Biochemistry, vol. 46, pp. 73-79, 2012.

[74] J. S. Cha, S. H. Park, S.-C. Jung et al., "Production and utilization of biochar: a review," Journal of Industrial and Engineering Chemistry, vol. 40, pp. 1-15, 2016.

[75] D. Mohan, C. U. Pittman, and P. H. Steele, "Pyrolysis of wood/biomass for bio-oil: a critical review," Energy \& Fuels, vol. 20, no. 3, pp. 848-889, 2006.

[76] Y. Wang, R. Yin, and R. Liu, "Characterization of biochar from fast pyrolysis and its effect on chemical properties of the tea garden soil," Journal of Analytical and Applied Pyrolysis, vol. 110, pp. 375-381, 2014

[77] C. Contescu, S. Adhikari, N. Gallego, N. Evans, and B. Biss, "Activated carbons derived from high-temperature pyrolysis of lignocellulosic biomass," C, vol. 4, no. 3, p. 51, 2018.

[78] M. Attalla and S. Sadek, "Experimental investigation of granular activated carbon/R-134a pair for adsorption cooling system applications," Journal of Power and Energy Engineering, vol. 2, no. 2, pp. 11-20, 2014.

[79] I. Khazaei, M. Aliabadi, and M. Ht Hamed, "Use of agricultural waste for removal of $\mathrm{Cr}$ (VI) from aqueous solution," Iranian Journal of Chemical Engineering, vol. 8, no. 4, 2011.

[80] Z. K. Chowdhury, Activated Carbon: Solutions for Improving Water Quality, American Water Works Association, Denver, CO, USA, 2013.

[81] M. Ilomuanya, B. Nashiru, N. Ifudu, and C. Igwilo, "Effect of pore size and morphology of activated charcoal prepared from midribs of Elaeis guineensis on adsorption of poisons using metronidazole and Escherichia coli $\mathrm{O} 157: \mathrm{H} 7$ as a case study," Journal of Microscopy and Ultrastructure, vol. 5, no. 1, pp. 32-38, 2017.

[82] D. M. Cuthbertson, "The production of pyrolytic biochar for addition in value-added composite material," 2018.

[83] Y. Lin, W. Yan, and K. Sheng, "Effect of pyrolysis conditions on the characteristics of biochar produced from a tobacco stem," Waste Management \& Research: The Journal for a Sustainable Circular Economy, vol. 34, no. 8, pp. 793-801, 2016.

[84] Y. Yue, Q. Lin, M. Irfan, Q. Chen, X. Zhao, and G. Li, “Slow pyrolysis as a promising approach for producing biochar from sunflower straw," BioResources, vol. 13, no. 4, pp. 7455-7469, 2018. 
[85] C. E. Brewer, Y.-Y. Hu, K. Schmidt-Rohr, T. E. Loynachan, D. A. Laird, and R. C. Brown, "Extent of pyrolysis impacts on fast pyrolysis biochar properties," Journal of Environmental Quality, vol. 41, no. 4, pp. 1115-1122, 2012.

[86] X. Liu, Y. Zhang, Z. Li, R. Feng, and Y. Zhang, "Characterization of corncob-derived biochar and pyrolysis kinetics in comparison with corn stalk and sawdust," Bioresource Technology, vol. 170, pp. 76-82, 2014.

[87] M. Laghari, Z. Hu, M. S. Mirjat et al., "Fast pyrolysis biochar from sawdust improves the quality of desert soils and enhances plant growth," Journal of the Science of Food and Agriculture, vol. 96, no. 1, pp. 199-206, 2016.

[88] C. E. Brewer, V. J. Chuang, C. A. Masiello et al., "New approaches to measuring biochar density and porosity," Biomass and Bioenergy, vol. 66, pp. 176-185, 2014.

[89] M. Dizbay-Onat, U. K. Vaidya, A. G. B. Jo, and C. T. Lungu, "Preparation and characterization of flax, hemp and sisal fiber-derived mesoporous activated carbon adsorbents," Adsorption Science \& Technology, vol. 36, no. 1-2, pp. 441457, 2018.

[90] J. Park, G. Lee, S. Hwang et al., "The effects of methane storage capacity using upgraded activated carbon by $\mathrm{KOH}$," Applied Sciences, vol. 8, no. 9, p. 1596, 2018.

[91] A. Aygün, S. Yenisoy-Karakaş, and I. Duman, "Production of granular activated carbon from fruit stones and nutshells and evaluation of their physical, chemical and adsorption properties," Microporous and Mesoporous Materials, vol. 66, no. 2-3, pp. 189-195, 2003.

[92] S. Wijitkosum and P. Jiwnok, "Elemental composition of biochar obtained from agricultural waste for soil amendment and carbon sequestration," Applied Sciences, vol. 9, no. 19, p. 3980, 2019.

[93] M. Ahmad, S. S. Lee, X. Dou et al., "Effects of pyrolysis temperature on soybean stover- and peanut shell-derived biochar properties and TCE adsorption in water," Bioresource Technology, vol. 118, pp. 536-544, 2012.

[94] P. Devi and A. K. Saroha, "Effect of temperature on biochar properties during paper mill sludge pyrolysis," International Journal of ChemTech Research, vol. 5, no. 2, pp. 682-687, 2013.

[95] Z. Wang, K. Liu, L. Xie, H. Zhu, S. Ji, and X. Shu, "Effects of residence time on characteristics of biochars prepared via copyrolysis of sewage sludge and cotton stalks," Journal of Analytical and Applied Pyrolysis, vol. 142, Article ID 104659, 2019.

[96] B. Zhao, D. O'connor, J. Zhang et al., "Effect of pyrolysis temperature, heating rate, and residence time on rapeseed stem derived biochar," Journal of Cleaner Production, vol. 174, pp. 977-987, 2018.

[97] K. H. Kim, J.-Y. Kim, T.-S. Cho, and J. W. Choi, "Influence of pyrolysis temperature on physicochemical properties of biochar obtained from the fast pyrolysis of pitch pine (Pinus rigida)," Bioresource Technology, vol. 118, pp. 158-162, 2012.

[98] L. Rosendahl, Biomass Combustion Science, Technology and Engineering, Elsevier, Amsterdam, Netherlands, 2013.

[99] A. Bridgwater and G. V. C. Peacocke, "Fast pyrolysis processes for biomass," Renewable and Sustainable Energy Reviews, vol. 4, no. 1, pp. 1-73, 2000.

[100] R. C. Brown and K. Wang, Fast Pyrolysis of Biomass: Advances in Science and Technology, Royal Society of Chemistry, Croydon, UK, 2017.

[101] J. Waluyo, I. Makertihartha, and H. Susanto, "Pyrolysis with intermediate heating rate of palm kernel shells: effect temperature and catalyst on product distribution," in AIP
Conference ProceedingsAIP Publishing, College Park, MD, USA, 2018.

[102] N. Jäger, J. Neumann, A. Apfelbacher, R. Daschner, and A. Hornung, "Two decades of intermediate pyrolysis: a major step towards CHP applicable bio-oils," in Proceedings of the 25th European Biomass Conference and Exhibition, EUBCE 2017, Stockholm, Sweden, June 2017.

[103] A. S. N. Mahmood, J. G. Brammer, A. Hornung, A. Steele, and S. Poulston, "The intermediate pyrolysis and catalytic steam reforming of Brewers spent grain," Journal of Analytical and Applied Pyrolysis, vol. 103, pp. 328-342, 2013.

[104] I. Y. Mohammed, F. K. Kazi, S. Yusup, P. A. Alaba, Y. Muhammad Sani, and Y. A. Abakr, "Catalytic intermediate pyrolysis of napier grass in a fixed bed reactor with ZSM-5, HZSM-5 and zinc-exchanged zeolite-A as the catalyst," Energies, vol. 9, no. 4, pp. 1-10, 2016.

[105] H. Chen, "Lignocellulose biorefinery conversion engineering," Lignocellulose Biorefinery Engineering, Woodhead Publishing, pp. 87-124, Cambridge, UK, 2015.

[106] A. Oasmaa and C. Peacocke, A Guide to Physical Property Characterisation of Biomass-Derived Fast Pyrolysis Liquids, Technical Research Centre of Finland Espoo, Espoo, Finland, 2001.

[107] T. Bridgwater, "Challenges and opportunities in fast pyrolysis of biomass: part I," Johnson Matthey Technology Review, vol. 62, no. 1, pp. 118-130, 2018.

[108] Y. Yang, J. G. Brammer, M. Ouadi et al., "Characterisation of waste derived intermediate pyrolysis oils for use as diesel engine fuels," Fuel, vol. 103, pp. 247-257, 2013.

[109] J. Samanya, A. Hornung, A. Apfelbacher, and P. Vale, "Characteristics of the upper phase of bio-oil obtained from co-pyrolysis of sewage sludge with wood, rapeseed and straw," Journal of Analytical and Applied Pyrolysis, vol. 94, pp. 120-125, 2012.

[110] M. Balat, M. Balat, E. Kırtay, and H. Balat, "Main routes for the thermo-conversion of biomass into fuels and chemicals. Part 1: pyrolysis systems," Energy Conversion and Management, vol. 50, no. 12, pp. 3147-3157, 2009.

[111] S. Czernik and A. V. Bridgwater, "Overview of applications of biomass fast pyrolysis oil," Energy \& Fuels, vol. 18, no. 2, pp. 590-598, 2004.

[112] J. Lehto, A. Oasmaa, Y. Solantausta, M. Kytö, and D. Chiaramonti, "Review of fuel oil quality and combustion of fast pyrolysis bio-oils from lignocellulosic biomass," Applied Energy, vol. 116, pp. 178-190, 2014.

[113] A. K. Azad, M. Rasul, B. Giannangelo, and R. Islam, "Comparative study of diesel engine performance and emission with soybean and waste oil biodiesel fuels," International Journal of Automotive \& Mechanical Engineering, vol. 12, 2015.

[114] J. Van Gerpen, R. Pruszko, D. Clements, and G. Knothe, "Biodiesel production technology," National Renewable Energy Laboratory, vol. 1617, pp. 80401-83393, 2004.

[115] A. Mahajan, A. Ahluwalia, and P. Mahajan, "Properties of biodiesel produced from various oilseeds," International Journal of Environmental Science and Technology, vol. 1, no. 4, pp. 26-29, 2011.

[116] Hamdan, A. Mohammad, and D. A. Almomani, "Performance study of a domestic boiler fueled by biodiesel produced from rapeseed," International Journal of Thermal \& Environmental Engineering, vol. 11, no. 1, 2016.

[117] M. T. Chaichan, "Combustion and emissions characteristics for DI diesel engine run by partially-premixed (PPCI) low temperature combustion (LTC) mode," International 
Journal of Mechanical Engineering (IIJME), vol. 2, no. 10, pp. 7-16, 2014.

[118] Q. Zhang, J. Chang, T. Wang, and Y. Xu, "Review of biomass pyrolysis oil properties and upgrading research," Energy Conversion and Management, vol. 48, no. 1, pp. 87-92, 2007.

[119] S. K. Hoekman, A. Broch, C. Robbins, E. Ceniceros, and M. Natarajan, "Review of biodiesel composition, properties, and specifications," Renewable and Sustainable Energy Reviews, vol. 16, no. 1, pp. 143-169, 2012.

[120] Q. Lu, X.-L. Yang, and X.-F. Zhu, "Analysis on chemical and physical properties of bio-oil pyrolyzed from rice husk," Journal of Analytical and Applied Pyrolysis, vol. 82, no. 2, pp. 191-198, 2008.

[121] A. S. Silitonga, H. H. Masjuki, T. M. I. Mahlia, H. C. Ong, W. T. Chong, and M. H. Boosroh, "Overview properties of biodiesel diesel blends from edible and non-edible feedstock," Renewable and Sustainable Energy Reviews, vol. 22, pp. 346-360, 2013.

[122] S. T. El Sheltawy, E. G. Al-Sakkari, and M. M. K. Fouad, "Waste-to-energy trends and prospects: a review," in Waste Management and Resource Efficiency, pp. 673-684, Springer, Berlin, Germany, 2019.

[123] M. Barz, M. K. Delivand, and K. Dinkler, "Agricultural wastes-a promising source for biogas production in developing countries of the tropical and subtropical regions," Revista Forestal Mesoamericana Kurú, vol. 16, no. 38, pp. 2-12, 2019.

[124] C. Del Pozo, J. Bartrolí, S. Alier, N. Puy, E. Fàbregas, and E. Fàbregas, "Production of antioxidants and other valueadded compounds from coffee silverskin via pyrolysis under a biorefinery approach," Waste Management, vol. 109, pp. 19-27, 2020.

[125] C. Del Pozo, J. Bartrolí, S. Alier, N. Puy, E. Fàbregas, and E. Fàbregas, "Production, identification, and quantification of antioxidants from torrefaction and pyrolysis of grape pomace," Fuel Processing Technology, vol. 211, p. 106602, 2021.

[126] Q. Yang, H. Zhou, P. Bartocci et al., "Prospective contributions of biomass pyrolysis to China's 2050 carbon reduction and renewable energy goals," Nature Communications, vol. 12, no. 1, pp. 1-12, 2021.

[127] J. O. Santos, H. Jahangiri, M. Asif Bashir, A. Hornung, and M. Ouadi, "The Upgrading of bio-oil from the intermediate Pyrolysis of waste biomass using steel slag as a catalyst," ACS Sustainable Chemistry \& Engineering, vol. 8, no. 50, pp. 18420-18432, 2020.

[128] J. Santos, M. Ouadi, H. Jahangiri, and A. Hornung, "Thermochemical conversion of agricultural wastes applying different reforming temperatures," Fuel Processing Technology, vol. 203, Article ID 106402, 2020.

[129] J. D. Martínez, F. Campuzano, N. Cardona-Uribe, C. N. Arenas, and D. Muñoz-Lopera, "Waste tire valorization by intermediate pyrolysis using a continuous twin-auger reactor: operational features," Waste Management, vol. 113, pp. 404-412, 2020.

[130] Aston University, "Intermediate pyrolysis," 2020, https:// www2.aston.ac.uk/eas/research/groups/ebri/research/ pyrolysis/intermediate-pyrolysis.

[131] L. Rosendahl, Biomass Combustion Science, Technology and Engineering, Woodhead Publishing Limited, Oxford, UK, 2013.

[132] R. H. Venderbosch, "A critical view on catalytic pyrolysis of biomass," ChemSusChem, vol. 8, no. 8, pp. 1306-1316, 2015. 